\title{
食に関連するタブーと俗信
}

\author{
黒田学
}

東北大学医学部公衆衛生学教室

\section{Taboo and Superstition in Dietary Habits}

\author{
Satoru KURODA \\ Department of Public Health, Tohoku University School of Medicine, Sendai, Miyagi
}

\begin{abstract}
An enquete survey on taboo and superstition in dietary habits was conducted for 435 nutritionists living in Miyagi Prefecture in April, 1975.

(1) The number of informations, in which something about taboo or superstition described, was 160. Most of them were concerned with diet of local people on prohibition of use of animal meat, cucumber, eel or a kind of beans.

The chief source of informations was the nutritionists working in the community health activity.

(2) The food prohibition was' reported to exist not only in rural, but also in urban areas, and the prohibitive regulation seems to have become weak along with the proceeding of modernization in the society.
\end{abstract}

(Received October 17, 1975)

ひとびとの食習慣の形成とそれに伴ら栄養摂取上の問 題を考えるらえで，食に関連するタブーと俗信を知るこ とは欠かすことができない。しかし，保健活動に従事す る専門家にとっては,タブーも俗信も，いわば「逃げ水」 のごとき現象として現われることが多く，その実態は必 ずしも明確にしがたい。

本研究は，宮城県内において，食に関連するタブーと 俗信が依然として存在しているといら前提に立って，そ れがどこに，どのようなものとして存在しているかを知 ろらとしたものである。この前提が誤りでなかったこと は, 調査の進行によって明らかとなったが, 調查開始前 の時点でる，たとえば，散発的ではあるが，農村地区の 食生活改善推進員などがその事例を報告したことがあ り，十分に根拠のある前提と考兄られた。

全県を対象とした調査にあたって，どのうにして情 報を収集すべきかが第一の問題点であった。たとえば， 各地区で自主的に活動している食生活改善推進員に質問 調查を行ならことも一つの方法として検討されたが，こ のひとびとがタブーや俗信を他人に知られたくないと考 える可能性のあることが障壁となると判断した。その意 味では, 各地区で働いている栄養士に対し質問調査を行 ならことが得策と考えられた。しかし，栄養士の場合， その土地で生まれ育ったものでないことが多く，必要と する情報への距離が遠いことが反面欠点となる。

ところで, 近年, 食に関連するタブーの調査が, 散発

$\overline{\mathbf{T}} 980$ 仙台市星陵町 2-1
的にではあるが世界各地ですすめられている。たとえ ば，妊娠分婏時の食のタブーに関して，マレーシフの漁

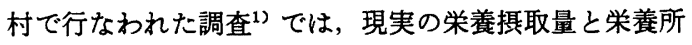
要量とが比較され，タブーが栄養摄取を抑制しているこ 之が指摘されている。また，妊娠・分婏・産褯・授乳・ 月経の各期間中および思春期における食のタブーに関し て, 西インド・タミルナド地方において行なわれた調

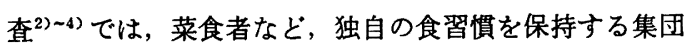
ごとに，タブー成立の背景について心理学的考察が加克 られている。また，魚に関する食のタブーの成立経過に 関して,アフリカ北東地域やインド・チベット地域に拉 いて, 歴史学や生態学の立場からの調査 ${ }^{576)}$ がみられる。 この種の調查は, 人類学的な方法（参与観察法など）を 用いていることが多く, 著者が今回とりあげた方法とは 質的に異なっている面が多い。著者は，ある小地域をと りあげ，その内部に立ち入っての調査を行ならことも考 慮しており，その方法による若干の事例研究も行なって いるが，それについては別に報告する予定である。

本報告では，したがって，地域に配置された栄養士と いう情報収集源を用いての横断的調査にかぎって報告す る。

\section{調 查 対 象}

宮城県内に居住する栄養士(管理栄㕌士を含む。以下, たんに栄盖士といら）435 名を対象とした。

栄養士の勤務の業態を病院給食, 学校給食, その他の 
表 1 . 栄養士の勤務の業態別の状況

\begin{tabular}{crc}
\hline 区 & No. & $\%$ \\
\hline 病 院 給 食 & 173 & 39.8 \\
学 校 給 食 & 65 & 14.9 \\
施設等の給食 & 66 & 15.2 \\
地 域 活 動 & 80 & 18.4 \\
そ の 他 & 51 & 11.7 \\
\hline 計 & 435 & 100.0 \\
\hline \hline
\end{tabular}

表 2. 栄養士の生活の場所別の状況

\begin{tabular}{|c|c|c|c|c|c|}
\hline \multirow{2}{*}{ 区 } & \multirow{2}{*}{ 分 } & \multicolumn{2}{|c|}{ 勤務地の所在 } & \multicolumn{2}{|c|}{ 自宅の所在 } \\
\hline & & No. & $\%$ & No. & $\%$ \\
\hline \multirow{2}{*}{\multicolumn{2}{|c|}{$\begin{array}{l}\text { 仙 台 市 } \\
\text { 仙台市以外 } \\
\text { の市部 }\end{array}$}} & 188 & 43.2 & 181 & 41.6 \\
\hline & & 115 & 26.4 & 106 & 24.4 \\
\hline 郡 & 部 & 132 & 30.4 & 148 & 34.0 \\
\hline & & 435 & 100.0 & 435 & 100.0 \\
\hline
\end{tabular}

施設等の給食に従事しているすの, 地域活動に従事して いるもの，拉よびその他の 5 群に分類して観察すると， 表 1 に示すように，病院給食には，173 名，約 4 割が従 事していてもっとも多く，給食従事者は総数が 300 名を こえて, 全体の 7割を占めている。地域活動に従事して いるむのは 80 名で, 全体の 2 割弱にすぎない。

栄養士の生活の場所を, 仙台市, 仙台市以外の市部, および郡部の 3 群に分類して観察すると, 表 2 亿示すよ らに, 勤務地の所在についても, 自宅の所在についてみ ても, 全体の 4 割強が仙台市にあり, 郡部は 3 割強にす ぎい。一方，昭和49年10月 1 日現在の宮城県推計人口 によって人口の分布をみると，仙台市 $31 \%$ ，郡部 $40 \%$ であるから，栄養士は相対的に都市部に集中していると いえる。また，郡部についてみると，自宅のあるるのの ほうか，勤務地のあるものより 16 名多い。

対象者の把握にあたっては, 日本栄盖士会宮城県支部 会員名簿と，宮城県保健所市町村栄羲士名簿を用いた。

\section{調 查 方 法}

因 1 に示した調査用紙を，返信用封筒とともに，原則 として自宅に郵送し，約20日後の期限まで，郵送により 回報するよう求めた。

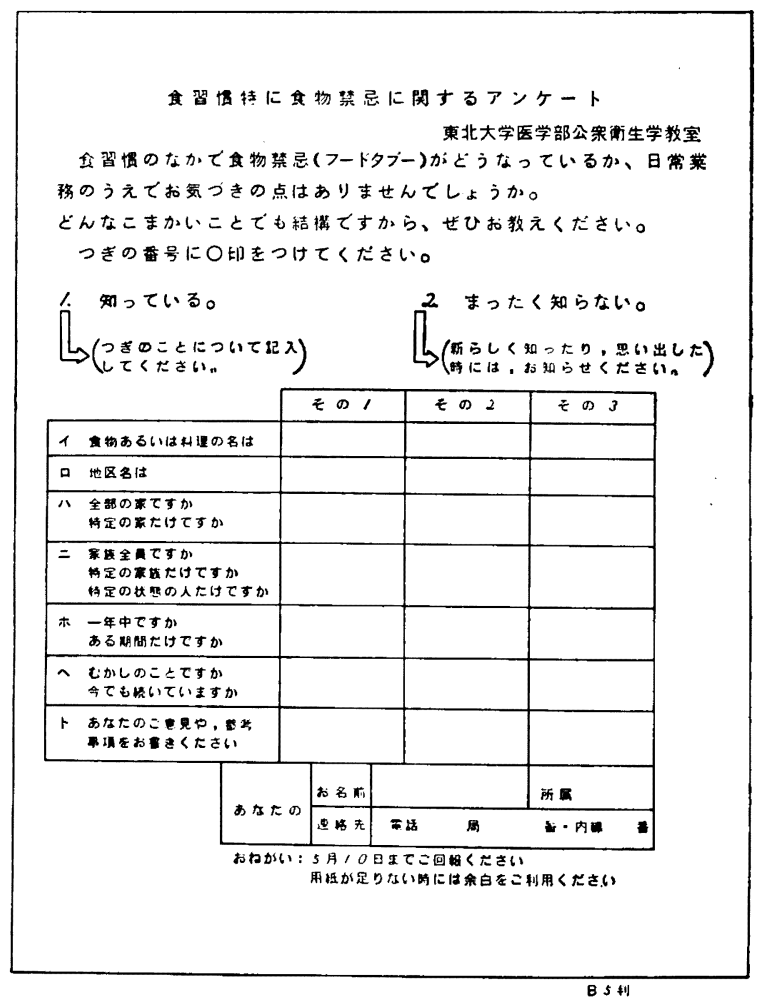

図1. 調查用紙 


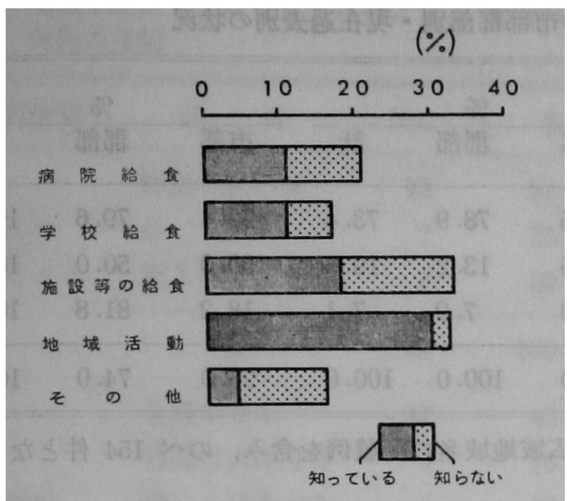

図 2. 栄荃士の勤務の業態別回報等の状況

なお，この調査は昭和 50 年 4 月から 5 月になされた。

\section{回 報 状 況}

435 名の対象者のうち, 103 名から回報が得られた(回 報率 : $23.7 \%$ )。

これを栄養士の勤務の業態別にみると，図 2 に示すよ 5に, 回報率では, 地域活動に従事している栄養士（以 下たんに地域活動群という。他の業態についても同じ） の $32.5 \%$, 施設等の給食群の $33.3 \%$ がめだっており, 他の 3 群にくらべて高率である（いずれる $p<0.05 ） 。$ また, 回報のうち, タブーや俗信に関する情報を含んで いる回報の割合をみると, 地域活動群の $92.3 \%$ が有意 に高率である（ $p<0.01 ） 。$

なお, 栄羮士の生活の場所別にみると, 回報率は, 勤 務地の所在についても, 自宅の所在についてみてる, 仙 台市，仙台市以外の市部，および郡部のいずれもが，ほ ぼ同じ割合を示しており，有意差は認められない。しか し，情報を含んでいる回報の割合をみると，勤務地の所 在については, 仙台市は郡部にくらぺて明らかに低く $(p<0.05)$ ，また自宅の所在についても，仙台市は他の 2 群にくらぺて，これも低率であって，いずれも有意差 が認められる（ $p<0.05 ） 。$

そこで, 勤務の業態と自宅の所在の場所との 2 要因が, 回報率と情報を含んでいる回報の割合に対しどのような 影響を与えているかを，2 元配固による分散分析によっ て検討を加えた。数値はすべて，逆正弦変換を行なった らえで計算したが，その結果は，回報率では勤務の業態 のほうがより大きく，また発送数に対する情報を含んで いる回報の割合，および回報数に対する情報を含んでい る回報の割合については, 勤務の業態のみが有意の变動 要因となっていた（表 3)。

$$
\text { 結 }
$$

果

提供された情報は，総数 160 件であり，提供者 1 人あ
表 3 . 栄養士の勤務の業態と自宅の所在に関する分 散分析・F 值 ( 2 元配置)

\begin{tabular}{|c|c|c|c|}
\hline 区 分 & 勤務の業態 & & 宅の所在 \\
\hline 回 報 率 & $36.72^{* *}$ & & 5. $17^{*}$ \\
\hline 情報提供率 & 9. $11^{* * *}$ & & 1.21 \\
\hline 情報数／回報 & $5.61^{*}$ & & 1.88 \\
\hline \multicolumn{4}{|c|}{${ }^{* *} p<0.01,{ }^{*} p<0.05$} \\
\hline \multicolumn{4}{|c|}{ 表 4. このたび提供された情報の内訳 } \\
\hline 区 & 分 & No. & $\%$ \\
\hline \multicolumn{2}{|c|}{$\begin{array}{l}\text { 食べてはいけない食品 } \\
\text { に関するもの }\end{array}$} & 145 & 90.6 \\
\hline \multicolumn{2}{|c|}{$\begin{array}{l}\text { 栽培してはいけない植物 } \\
\text { にするもの }\end{array}$} & 12 & 7.5 \\
\hline \multicolumn{2}{|c|}{$\begin{array}{l}\text { 飼養してはいけ関するもの } \\
\text { 動物 }\end{array}$} & 2 & 1.3 \\
\hline \multicolumn{2}{|l|}{ そ の 他 } & 1 & 0.6 \\
\hline \multicolumn{2}{|l|}{ 計 } & 160 & 100.0 \\
\hline
\end{tabular}

表 5 ．食べてはいけない食品に関する情報のタブー 俗信別の状況

\begin{tabular}{|c|c|c|}
\hline 区 & No. & $\%$ \\
\hline タブーと思われるもの & 113 & 77.9 \\
\hline 俗信と思われるもの & 27 & 18.6 \\
\hline $\begin{array}{l}\text { 記載内容からはいずれ } \\
\text { とも区分できないすの }\end{array}$ & 5 & 3.5 \\
\hline 計 & 145 & 100.0 \\
\hline
\end{tabular}

たり平均 2.5 件である。

これを，食べてはいけない食品，栽培してはいけない 植物, 飼荃してはいけない動物等に分類すると, 表 4 に 示すょうに，大部分は，食べてはいけない食品に関する 情報である。

食べてはいけない食品に関する 145 件の情報を，タブ 一と思われるもの，俗信と思われるもの，および記載内 容からはいずれとも区分できないものと 3 群に分類を試 みると, 表 5 に示すごとくである。分類の基準は, 日本

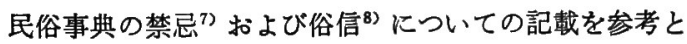
し，タブーと思われるものには，ひとびとがそれを神聖 なるのと考劣るか，あるいは不浄なるのと考えるかのい ずれかの理由によって，さらには，それら神聖なものあ 
表 6. 食べてはいけない食品に関する情報の市部郡部別・現在過去別の状況

\begin{tabular}{|c|c|c|c|c|c|c|c|c|c|}
\hline \multirow{2}{*}{ 分 } & \multicolumn{3}{|c|}{ No. } & \multicolumn{3}{|c|}{$\%$} & \multicolumn{3}{|c|}{$\%$} \\
\hline & 市部 & 郡部 & 計 & 市部 & 郡部 & 計 & 市部 & 郡部 & 計 \\
\hline 現在む行なわれている & 23 & 90 & 113 & 57.5 & 78.9 & 73.4 & 20.4 & 79.6 & 100.0 \\
\hline 昔のことである & 15 & 15 & 30 & 37.5 & 13.2 & 19.5 & 50.0 & 50.0 & 100.0 \\
\hline その 他 & 2 & 9 & 11 & 5.0 & 7.9 & 7.1 & 18.2 & 81.8 & 100.0 \\
\hline 計 & 40 & 114 & 154 & 100.0 & 100.0 & 100.0 & 26.0 & 74.0 & 100.0 \\
\hline
\end{tabular}

備考 1）宮城県内の地名を記載した 120 件について，2）広域地域名の記戴例を含み，のペ 154 件となる

るいは不浄なものと関連するものと認めていることによ って，摂食が㧕制されている場合をとりあげた。また， 俗信と思われるものには，タブーの場合ほど明瞭に, 清 浄・不浄あるいは聖・俗の観念と結びついていないもの を含めることとした。いわゆる食い合わせについては， 俗信に分類した。実際には, 情報の記載がこれらの点に ついて必ずしも十分でなく，ときにかなり怨意的な分類 となった。提供された情報がタブーの範ちゅうに属す るかあるいは俗信とすべきかは，より精細な個別の調査 によらなければ明らかになしえない。そのため，本報告 では，をめていわゆる禁忌として扱った。

食べてはいけない食品に関する 145 件の情報のらち, 宮城県内の地名を記載した 120 件を，市町村別および現 在過去別に整理すると，表 6 のごとくである。整理にあ たっては, 異なった情報提供者によるものでも, 同一地 域に関すると判断される情報は統合し，また広域地域名 が記載されている場合は，そこに含まれる市町村ごとに それぞれ算定することとした。

さらに, 都市農村別の分布の状況を検討するため, 市 町村別第 1 次産業就業者割合（昭和 45 年国勢調査）と並
表 7. 食べてはいけない食品に関する情報の食品の 種類別の状況

\begin{tabular}{|c|c|c|}
\hline 分 & No. & $\%$ \\
\hline 四足 -二足 & 40 & 27.6 \\
\hline きゅうり & 17 & 11.7 \\
\hline らなぎ & 16 & 11.0 \\
\hline あずき & 6 & 4.1 \\
\hline たにし，たまご, せり，たこ & 各 4 & 省略 \\
\hline $\begin{array}{l}\text { さかな, かぼちゃ,さけ， } \\
\text { たら, かきなす, なち }\end{array}$ & 各 3 & 省略 \\
\hline その 他 & 29 & 省略 \\
\hline 計 & 145 & 100.0 \\
\hline
\end{tabular}

直して示すと図 3 のごとくであって，農山漁村のみでな く, 宮城県内のいたるところに存在していることがわか る。

食べてはいけない食品に関する 145 件の情報を, 食品 の種類別に分類すると，表 7 のごとくである。件数の多
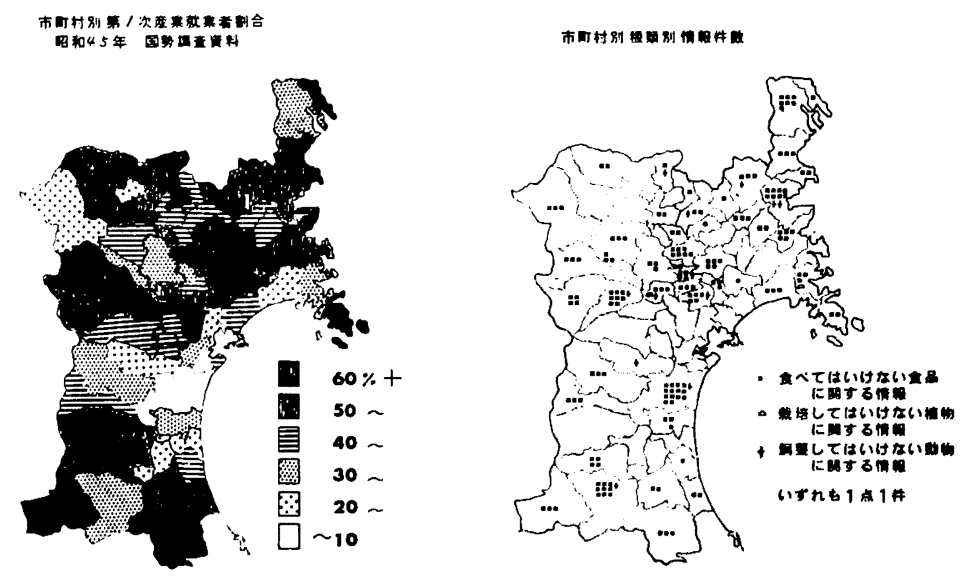

図 3. 市町村別にみた情報分布状況と第 1 次産業就業者割合との関連 
表 8. 現在す四足・二足を食べないとする 25 件の 情報の分析

\begin{tabular}{|c|c|c|c|}
\hline 分析事項 & 区 分 & No. & $\%$ \\
\hline & 特定の家のみ & 13 & 52.0 \\
\hline 地域内の & 全戸 & 7 & 28.0 \\
\hline \multirow[t]{4}{*}{ ひろがり } & 記入のないもの & 5 & 20.0 \\
\hline & 計 & 25 & 100.0 \\
\hline & 全員が守る & 12 & 48.0 \\
\hline & 特定の人が守る & 4 & 16.0 \\
\hline 家族内の & 若い人は食べる & 4 & 16.0 \\
\hline \multirow[t]{6}{*}{ ひろがり } & 妊婦が守る & 1 & 4.0 \\
\hline & 記入のないもの & 4 & 16.0 \\
\hline & 計 & 25 & 100.0 \\
\hline & 年間を通じて & 9 & 36.0 \\
\hline & 正月の期間 & 6 & 24.0 \\
\hline & 服喪期間 & 4 & 16.0 \\
\hline \multirow[t]{6}{*}{ 禁止の期間 } & 孟蘭盆 & 2 & 8.0 \\
\hline & 彼岸の時期 & 1 & 4.0 \\
\hline & 正月と命日 & 2 & 8.0 \\
\hline & 妊娠期間中 & 1 & 4.0 \\
\hline & 計 & 25 & 100.0 \\
\hline & $\begin{array}{c}\text { よそで食べるのは } \\
\text { かままい }\end{array}$ & 2 & 8.0 \\
\hline \multirow[t]{3}{*}{ 禁止の場所 } & $\begin{array}{c}\text { 屋外で煮炊きすれ } \\
\text { ば差し支えない }\end{array}$ & 1 & 4.0 \\
\hline & 記入のないもの & 22 & 88.0 \\
\hline & 計 & 25 & 100.0 \\
\hline
\end{tabular}

備考 : 宮城県内の情報のみ

い順に列挙すると，四足・二足の動物 40 件，きゅらり 17件，5なき 16 件，あずき 6 件が上位に並び，この 4 種類ですでに過半数 (79/145) を占めている。このほか, 4 件ずつの 4 種類, 3 件ずつの 7 種類などが 続いてい る。

四足・二足の動物を食べないとする 40 件の情報のう ち, 宮城県内の地名が記載され, しかる現在むなお存在 している 25 件について, 地域内のひろがり, 家族内の ひろがり, 禁止の期間, および禁止の場所について分析 すると，表8に示すごとくである。すなわち，地域内に おいては，いわゆる旧家や老人のいる家など，特定の家 の 13 件がすっとも多いが, 全戸とするものも 7 件みら れる。家族内のひろがりについては，全員が食べないと する 12 件が，注淁数を占めている。「老人などの特定
表 9.きゅらりを食べないとする17件の情報の分析

\begin{tabular}{|c|c|c|c|}
\hline 分析事項 & 区 分 & No. & $\%$ \\
\hline & 全 戸 & 8 & 47.1 \\
\hline 地域内の & 特定の家のみ & 6 & 35.3 \\
\hline \multirow[t]{3}{*}{ ひろがり } & 記入のないもの & 3 & 17.6 \\
\hline & 計 & 17 & 100.0 \\
\hline & 全員が守る & 10 & 58.8 \\
\hline 家族内の & 家長が守る & 2 & 11.8 \\
\hline \multirow[t]{4}{*}{ ひろがり } & 老人が守る & 1 & 5.9 \\
\hline & 記入のないもの & 4 & 23. 5 \\
\hline & 計 & 17 & 100.0 \\
\hline & $\begin{array}{l}\text { 祭礼に奉納する } \\
\text { 以前の期間のみ }\end{array}$ & 9 & 53.0 \\
\hline \multirow[t]{4}{*}{ 禁止の期間 } & 年間を通じて & 5 & 29.4 \\
\hline & 記入のないもの & 3 & 17.6 \\
\hline & 計 & 17 & 100.0 \\
\hline & $\begin{array}{c}\text { 現在む行なわ } \\
\text { れている }\end{array}$ & 11 & 64.8 \\
\hline 過去現在 & 昔のことである & 3 & 17.6 \\
\hline \multirow[t]{2}{*}{ の別 } & そ の 他 & 3 & 17.6 \\
\hline & 計 & 17 & 100.0 \\
\hline
\end{tabular}

の人が食べない」とする記載と,「若い人は守らない。 食べる」といら記載は, 家族内のひろがりといら点で, おそらく内容はほぼ同しであろらと推定される。禁止の 期間については，年間を通じてとする情報が，9件， $36 \%$ 提供されているが，期間を限定している情報は，正 月の期間と, 葬送にかかわる期間との 2 種類に, ほぼ大 別できる。妊婦および妊娠期間にかかわる 1 件は, 宮城 県北西部に位置する山村に搱ける，鬼肉を食べてはいけ ないとする情報である。なお，禁止の期間には，ある特 定の時点に打ける 1 食だけのものから，1 力月間に及ぶ るのが含まれている。禁止の場所については, 許容され る場合が 3 件あげられている。そのらち，自宅以外の場 所で食へるのはかまわないとする 2 件は，いずれも年間 を通じて守られている例で，ともに，「若い人たちはよ そで食べると添記されている。

きゅうりを食べないとする 17 件の情報を, 四足・二 足の場合と同様の観点から分析すると, 表 9 に示すごと くである。ある地域内に批るひろがりについては，全 戸と記載した 8 件がすっとも多く, 特定の家とする 6 件 がこれに次いでいる。しかし，この地域的なひろがり方 
については, 情報提供者の認識によって変わるようで, 大字程度あるいは小字名と思われる地名を記載した例で は, 大多数が「全戸」と記載され，市町村名や市町村合 併前の旧町村名と思われる地名を記載した例では，「(氏 子など）特定の家」と記载されているものが多い。これ らは，河童信仰や天王信仰などに関係して，氏子が守ら なければならないとされている例が多い。禁止の期間に ついては，祭礼に初物を奉納する以前の期間にのみ食べ られないとする情報が過半数を占めており, 祭礼の時期 を記載したもののなかでは，6月が多い。しかし，年間 を通じて，あるいは一生崖のあいた食へられない例も少 なくない。宮城県の三陸沿岸に位固するある漁村（O町 M落部）では，住民のほぼ全員が，現在も年間を通じて 守り続けていて, 学校給食に䏅しても, その部落の児童 のみはきゅらりを食べ残すといら事例が提供されてい る。全数 17 件のうち, 11件は現在も存在していること がわかる。なお，栽培す禁止されている例が 1 件含まれ ている。

らなぎを食べられないとする情報は, 宮城県北柬部の 農村地帯を中心に，16件が提供されている。このうち， 軣村地帯にあるT町（人口 1 万 5 千人, 第 1 次産業就業 者割合 60\%) について, ほぼ同じ内容のものと推定され る 4 件の情報が, 同町居住者ではない 4 名の栄養士から それぞれ個別に提供されている。16件のらち，10件は虚 空蔵菩薩信仰との関連が深く，氏子のうち十二支のある 特定の年に生まれた者は一生涯食べられないといら内容 が記載されている。この十二支については, 丑年, 寅年, 巳年の 3 種類がみられる。なお，4件については，「らな ぎの絵馬を奉納すれば許される」と添記されている。

あずきまたはあんこもちを食べられないとする情報 は, 宮城県北東部の農村地帯を中心に，6件が提供され ている。いずれも，ある特定の家では，家族全員が，正 月の期間には食べられないとする内容が記載されてい る。禁止の期間については, 正月の 3 日間のものから, 正月の15日間に及ぶものが含まれている。禁止の場所に ついては, 許容される場合が 1 件あげられていて，「自 宅以外の場所で食べるは差し支えない」と添記されて いる。なお，もち(たんにもちとのみ記載されている)を 食べられないとする情報が，ほかに3件提供されてい る。しかし, 禁止の期間はいずれも正月以外の時期であ って 3 件ともそれぞれ異なっているらえに, 存在してい る地域る, 宮城県南部地域や福島県と記載されているこ となどから勘案すると，このたび提供された情報からみ る限りでは，それぞれ別個の，異質の情報と推定され る。

たにし（またはつぶ）を食べられないとする情報は， 宮城県北西部に位置する農村の事例として，4件提供さ
れている。このらち3件は, 小地域において, 全戸が現 在も守り続けているといら内容のものであるが, 細部に ついては記載されていない。

このほかの食品については割愛する。

栽培してはいけない植物について，12件の情報が提供 されている。1 件について，1種類ないし 5 種類の植物 名が記載されているが，重複している植物が多いので, 全件を通じて，ねぎ，かぼちゃ，なす，ごぼら，とうむ ろこし,きゅうり,くるみ,ごま,およびさといすの 9 種類がみられた。な拉，3件については，「食べてもか まわない」と添記されている。

飼㽰してはいけない動物に関する情報は，2件提供さ れている。 ちち 1 件は，爪の割れた動物について，飼盖 してはいけないが，肉や乳は食へてても差し支えないとす る事例である。他の 1 件は，にわとりの飼荃にかかわる 情報であるが，食べることについては記戴されていな W。

その他の 1 件は, 岩手県下における澷村家庭衣食住実 態調査報告（1956年）の一部を，参考資料として提供さ れたものである。

\section{考察}

文化は生活習慣に多様な影響を与える。ひとびとの持 つ各種の信仰は文化の一つの表現型と考えることができ るが，それが素朴な土着信仰であれ，あるいはまた，高 次の宗教の形態をとる場合であっても，いろいろな内容 の食に関連するタブーがそれによって説明されることが 多い。タブーは，ある社会に打ける社会的制度の一つと して理解され，しかも，それを破ることに対し，社会的 懲罰が課せられることを特徵としている ${ }^{9)}$ 12)。

本邦では，最近，九州地方において，「食物タブーの 調查研究 ${ }^{13)} 」 と$ 題する報告があり，また東北地方におい

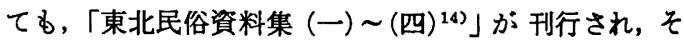
のなかに食に関連するタブーが記述され，あるいは，古 老たらからの聞き書きの一部として触れられてはいる が，いずれも敬発的記載に留まっている。

著者は，宮城県内において，食に関連するタブーと俗 信が依然として存在するといら前提に立って調査を開始 した。提供された 160 件の情報のらち，食べてはいけな い食品に関するすので，さらに宮城県内の地名を明記し た 120 件の情報を分析したところ，現在も行なわれてい るものは $73.4 \%$, 市部に存在しているものは $26.0 \%$ を 占めており，第 1 次産業就業者割合の高い费山漁村ばか りでなく，市部（仙台市など11市）をむ含む県内いたる ところに存在していることが判明した。県都である仙台 市（人口約 55 万人，第 1 次産業就業者割合約 $5 \%$ ）に おいても，現在なお，7種類のタブーまたは俗信が存在 
てており，著者の前提は正しかったと考える。

四足・二足の動物の摂食のタブーは，このたびの調査 水いて，提供された件数がすっとす多かった。ここで とりあげておくべきとは，いわゆる旧家ではない新し 、家や若い人たちのあいだでは, このタブーが, 現在で は守られなくなってきている傾向がらかがわれることで ある。このほか, 自宅以外の場所における提食が許容さ れたり，あるいは，葬送習俗としてのいわゆる精進おと しが早められて行なわれるなど，禁止の期間が短縮され る傾向にある。

全般的に観察すると，タブーを社会内部に保持する力 は, 時代の進展に伴って減弱しつつあるようにみえる。 しかし，個々のタブーについては，その保持されている 状態のいろいろのすのが含まれている。

きゅうりを食べないとするO町M部落の例では, 前述 の全般的傾向に反して, 小学校児童のような若年者が, 学校側の給食指導にもかかわらず，同部落の児童のみが そろって食へ残すという。これは，きゅうりの摂食のタ ブーが全住民に深く浸透し, 強力に保持されている例で ある。

らなぎを食べられない下町の例では，ほぼ同一と思わ れる内容について 4 名の情報提供者が存在しており，宮 城県内ではよく知られた，有名なタブーと思われる。

栄䖯士を対象にしたフンケート調査を実施したことに ついて，ここで考察を加えておきたい。すでに述べたよ らに，宮城県内におけるタブーや俗信の横断的調查とい ら锶点からは，一応の成果を得ることができたといえ る。この調查によって, 総数 160 件に及ぶ情報を得るこ とができ,これに基ついて，小地域における事例研究に 発展させること,ならびに，栄養士の勤務の業態別に情 報収集源としての意義を恰討することが可能であった。 有用な情報を多く提供する要因としては，勤務の業態が 有意の変動要因であることが判明し, 地域活動に従事す る栄養士の特異性が浮彫りにされた。地域活動を行なっ ている栄盖士は，地域住民の日常の食生活（厷義の）の 現況をまず把握することにはじまり，各種のプログラム を企画したうえで，地域内にはいりこむことによって栄 養指導に従事している。そのために, 他群にくらべて, 相対的にタブーや俗信への距離が近いことは明らかであ る。

なお，施設等の給食群が地域活動群に近い態度を示し ている理由として，著者はまず人事交流の影響をあげた い。一般に, 病院給食群户学校給食群の人事移動は, 現 状では閉鎖的であるのに反して, 公立の福祉施設等 (今 回の調査では施設等の過半数を占めている）に勤務する 栄巻士と地域活動に従事する栄養士は, 公務員としての 身分が同一であるところから，人事交流（群間移動）が
かなり実施されている。そのため, 地域活動経験者が施 設等給食群のなかに含まれている。さらに, 分類の便宣 上，栄養士や調理師の養成機関（大学など）の勤務者す この群に含めたが, 実際には, これらの勤務者から多く の有用な情報が提供されていることを付言したい。

\section{結語}

本研究は, 宮城県内において食に関連するタブーと俗 信が依然として存在するという前提に立ち, 栄養士を情 報収集源として横断的調査を実施したものである。

1）宮城県内に居住する栄盖士 435 名に対し, 昭和50 年 4 月にアンケート調查を実施した(回報率 : $23.7 \%$ )。

2）提供された 160 件の情報のうち，食べてはいけな い食品については 145 件, $90.6 \%$ であり, そのうらタ ブーと判断されるものは113件，77.9\%を占めていた。

3）食べてはいけない食品に関する情報を分析したと ころ, 現在も行なわれているすのが $73.4 \%$ を占めてい ること，および，都嗗の別なく県内いたるところに存在 していることが判明した。

4）獣肉を食へてていいけないとする情報は 40 件にの ぼり，そのうち，25件は現在む行なわれているるのであ った。この情報を新旧別等に分析してみると，タブーを 社会内部に保持する力は, 時代の進展とともに減弱する 傾向にあることがらかがわれた。

5）栄養士からの情報提供状況を分析したところ，タ ブーや俗信に関する有用な情報の回報といら点では, 地 域活動に従事する栄養士がもっとも重要であった。

たえずご指導を賜わった東北大学医学部公臬街生学教 室鉿木継美教授に深く感謝申しあげる。また，調査にご 協力をいたたいた日本栄養士会宮城県支部野口丑松支部 長はじめ会員の栄盖士各位に厚くお゙礼申しあげる。

なお, 本研究の一部を, 昭和50年度日本栄養 ・食糧学 会東北支部大会において発表した。

\section{文献}

1) Wilson, C.S. : Ecology of Food and Nutrition, 2, 267 (1973)

2) Ferro-Luzzi, G.E. : Ecology of Food and Nutrition, 2, 165 (1973)

3) Ferro-Luzzi, G.E. : Ecology of Food and Nutrition, 2, 259 (1973)

4) Ferro-Luzzi, G.E. : Ecology of Food and Nutrition, 3, 7 (1974)

5) Simons, F.J.: Ecology of Food and Nutrition, 3, 89 (1974)

6) Simons, F.J.: Ecology of Food and Nutrition, 3, 185 (1974)

7）今野円助：「祭忌」(大塚民俗学会編)，日本民俗事 典, 212 (1972), 弘文堂, 東京

8）宫田 登:「俗信」(大塚民俗学会編)，日本民俗事 
典, 401 (1972), 弘文堂, 東京

9) Frazer, J.G. (永橋卓介訳): The Golden Bough (金枝編) (1963)，岩波畫店，東京

10) Steiner, F.B.: Taboo,(1967), Cox \& Wyman, London

11) Garine, I.D.: Ecology of Food and Nutrition, 1,143 (1972)
12) Todhunter, E.N.: World Reviews of Nutrition and Dietics, 16, 286 (1973)

13）園田直人, 野原常子 : 栄養学雜誌, 33, 31 (1975)

14）岩崎敏夫編：東北民俗資料菜 (一) (四)，(1971 1975), 万葉堂書店, 仙台

(昭和 50 年 10 月 17 日受理) 